\title{
IMPORTANCE OF TREES OUTSIDE FOREST (TOF) FOR IMMEDIATE EARTHQUAKE RESPONSE
}

\author{
Ghimire, P., P. Paudel ${ }^{1}$, B. Bhatta, P. Gautam ${ }^{1}$ and N.Devkota ${ }^{2}$ \\ Faculty of Forestry, Agriculture and Forestry University, Hetauda, Nepal; ${ }^{1}$ Practical Solution \\ Consultancy Nepal, Pvt. Ltd., Kathmandu, Nepal; ${ }^{2}$ Faculty of Agriculture, Agriculture and Forestry \\ University, Chitwan, Nepal
}

\begin{abstract}
A study was carried out in Thulosirubari village of Chautara Sangachowkgadi municipality of Sindhupalchok district, Nepal to analyse the importance of TOF for immediate earthquake response and recovery. More than $80 \%$ of the households have trees in their own land with species such as Chilaune (Schima wallichii), Kutmiro (Litsea monopetala), Khote Salla (Pinus roxburghii) and Bamboo are common. Among surveyed households (134), more than $75 \%$ respondents reported that they used Schima wallichii for pillar (Khaba) to make temporary houses, whereas bamboo was used for all kind of poles (Dada/Vata/Balo) in more than $80 \%$ of temporary houses. Both Bamboo and Schima wallichii were either extracted from their own land or from neighbour's land, i.e. TOF which were easily available and collected as required. We could not draw any statistical conclusion in choice of species to construct temporary houses by wealth categories. However, we have observed that people who have sufficient and varieties of trees in own land, have selected strong and hard wood for permanent house construction whereas those who do not have choice, are limited to use any of the available tree species. People were highly aware about importance of trees to cope with disaster; however selection of species was still debatable because of limited knowledge and researches.
\end{abstract}

Key words: Bamboo; Earthquake; Temporary houses; Trees outside forest.

\section{INTRODUCTION}

Nepal experienced a catastrophic earthquake of magnitude 7.6 on 25 April and major aftershock on 13th May 2015, followed by more than 400 aftershocks (MoSTE 2015). This was one of the worst earthquakes in recent history of Nepal. It led to wide spread devastation, affecting 31 of the country's 75 districts (NPC 2015) and more than 8 million people. About 9,000 people lost their life, 22,220 were injured, and over 100,000 people were completely or partially displaced (MoHA 2015). Initially it was estimated that it induced at least 2,780 landslides and many ground cracks in 31 districts, significantly damaging settlements, infrastructure, agricultural land, forests and water resources; the frequency of landslides was three times greater than that before the earthquake (MoSTE 2015). However, later Gnyawali et al. (2016) identified more than 17,000 landslides triggered by earthquakes in the 14 affected districts, which shows that actual loss of property can be significantly higher than previously thought. It also caused extensive damage to physical and economic infrastructure including thousands of houses, schools, hospitals, government offices, roads, irrigation canals and market centres. More than 2,600 government buildings and 602,257 private houses were completely destroyed. Similarly, 3,757 government buildings and 285,099 private houses were partially damaged (MoHA 2015). This caused great destruction in human normal living pattern and human life style. People are compelled to live (construct) in temporary houses or shelter using locally available materials such as bamboos, reusing timber from existing house, zinc plates and other materials provided by the government and Nongovernment organisation as a relief materials (MoHA 2015). Timber was extracted for every possible and easy available sources mainly from old damaged houses, trees in farmland (trees outside forest) and community forest etc. (Shrestha et al. 2016).

Trees outside forest (TOF) includes all trees that exist beyond the forest and other wood land (FAO 2004) i.e. trees in cities, on farms, along roads, in fruit-tree plantations and in home gardens (West 
2009). Inclusion of TOF can be interpreted as an important recognition of the national and global relevance of this resource for human livelihoods, the environment, and biodiversity (Schnell 2015, Schnell et al. 2015). Trees and shrubs are important component of Nepalese rural households (Amatya 2018). Although the Nepalese tree resources outside forest can play a valuable role for enhancing sustainable development and people's livelihoods (FAO 2003, Giri 2004), the main focus has always been more on trees in forests that are viewed as a resource and a store of biological diversity (Nepal 2015). In addition, TOF (trees grown on farmland, in and around homesteads and human settlements, in road and canal side and in other land use categories) have not been included in national forest inventory, even though they have diverse functions for wellbeing of humankind and in maintaining the natural environment (Amatya 2018, Oli 2002). Therefore, this study attempts to explore the importance of TOF in immediate earthquake recovery/response and need during disastrous time especially for construction of temporary houses and shelter.

\section{Study Area}

\section{METERIAL AND METHODS}

Sindhupalchok in one of the worst-affected district among 14 districts of Nepal during 2015 Earthquake (NPC 2015). The initial epicenter of the 2015 earthquake was in Gorkha district, the highest magnitude aftershock, 6.7 rector scale, occurred in Dolakha district (Benfield 2015). Similarly, more than 100 aftershocks epicenter were located in Sindhupalchok district (MoHA 2015). Among 79 Village development committee, Thulosirubari $(2,047 \mathrm{ha})$ is one of the highly affected villages, where major land use system is agriculture and forestry. National record from government of Nepal shows that more than $1200(>90 \%)$ houses were partially or fully damaged where reconstruction process has been just began (MoHA 2015).

Population census 2011 shows that there are 1,331 household where 5,987 people are resident (2,632 Male and 3,355 Female). Majority of the houses are made by mud-bounds stones walled (CBS 2012). Wood is the primary source of energy for cooking purpose in this VDC (DDC 2016) followed by LPG gas. Similarly, livestock rearing is another source of income for people in this VDC (CBS 2012). Plantation or conservation of trees in agriculture system has been long practiced in the area where trees preserve in farmland for multiple purposes.

\section{Data Analysis}

This study was based on primary data collected in April 2017. Semi-structured questionnaire survey was used to assess the importance of the TOF (farm trees) on immediate earth-quake recovery. Simple random sampling was applied for selecting households for questionnaire survey. Altogether 134 households were sampled for this study ( $(90 \% \mathrm{CI}$ and $10 \%$ margin of Error). Other primary data were collected through field observation, key informant's survey and informal meetings. The secondary data were compiled from the district profile and other related documents and fitted to the study accordingly. Collected information was coded and analyzed through $\mathrm{R}$ for statistical package and presented in the form of chart, tables etc.

\section{Trees on farmland and their position}

\section{RESULTS AND DISCUSSION}

The study shows that in Thulosirubari village, more than $77 \%$ of the households have trees on their own farmland. Households having limited land did not have trees on farmland, which was optimized for agriculture production. Trees were conserved in different possible location, basically in terrace raiser (72.73\%) followed by fallow land $(68.18 \%)$. There were few HHs having trees near house (form of home garden) and near river slope for control of river bank erosion (Fig.1). 
Since the study area was in mid-hills of Nepal where Chilaune (Schima wallichii) is one of the main species that naturally grows in this area. Similarly in our study site Chilaune $(68.18 \%)$, Kutmiro (Litsea monopetala) (63.64\%) and Bamboo (Bambusa species) $(56.77 \%)$ were major plant species available (Fig. 2). Apart form Bamboo only few number of fodder species like Litsea monopetala were planted in terrace raiser where other species were naturally grown in those location. Species like Chilaune, Sal (Shorea robusta), Utis, Pine are used for timner and fire wood where as Bamboo was prefer as pole and other supporting timber in construction. Now-a-days species like Lapsi (Choerospondias axillaris), Haluwabed (Diospyros kaki) etc. are planted in home garden for fruit production at household level.

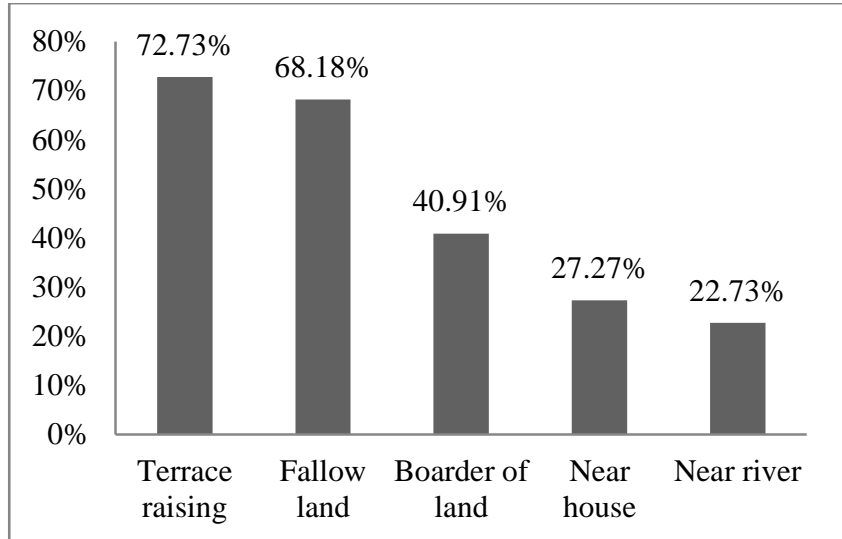

Fig.1. Location of tree species in the farm land.

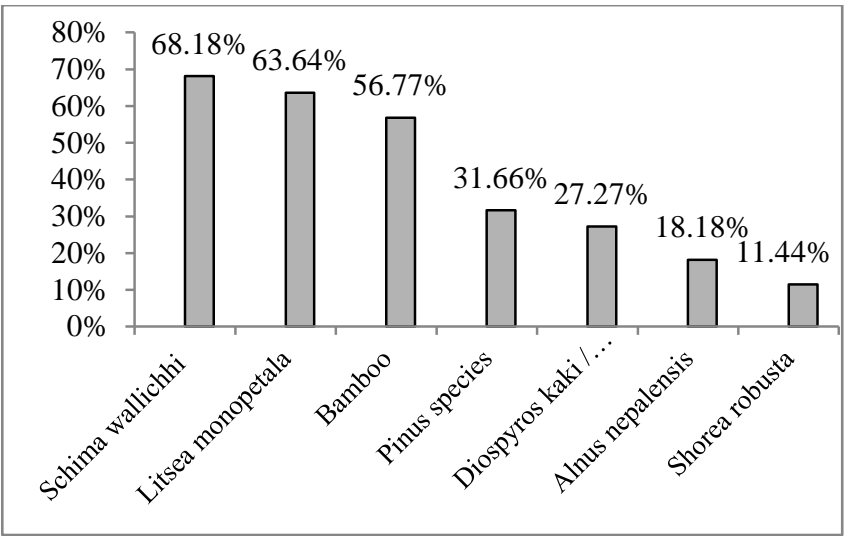

Fig. 2. Frequency of species present in Farmland.

\section{Source of timber for temporary house construction}

In the study area, there were various sources of timber for construction of temporary houses. Among various sources of timber, collection or extraction from TOF (from own land) was very high (0-100\%) followed by old house (0-80\%), neighborhood TOF (0-30\%) and few HHs collected from community forest or purchase. In an average, contribution of TOF for temporary household construction was more than $70 \%$, which includes TOF in own land or in neighborhood land. Households having enough trees on farmland are collected or extracted as required timber from their own land that was supplemented by timbers from old houses. For those who did not have trees on their own land mostly extract timber from old houses, collect from Community Forests, purchase or burrow from neighborhood TOF.

Table 1. Source, ranges and average contribution from various sources of timber for construction of temporary houses.

\begin{tabular}{lcl}
\hline Source & Percent ranges (Average \%) & Remarks \\
\hline Own land (TOF) & $0-100(62 \%)$ & Having sufficient trees in own land \\
\hline Neighborhood land (TOF) & $0-30(9 \%)$ & $\begin{array}{l}\text { Don't have tress on own land } \\
\text { Mainly Bamboos was collected }\end{array}$ \\
\hline Old House (damaged/ destroyed) & $0-80(21 \%)$ & $\begin{array}{l}\text { Every house used some form of timber but not over } \\
\text { exploited }\end{array}$ \\
\hline Purchase & $0-30(2 \%)$ & $\begin{array}{l}\text { Don't have trees on own land } \\
\text { Bamboos from neighborhood house/ village. }\end{array}$ \\
\hline Community Forest & $0-40(6 \%)$ & $\begin{array}{l}\text { Don't have trees on own land and other possible } \\
\text { sources }\end{array}$ \\
\hline
\end{tabular}


Species use for construction of temporary houses

Temporary shelter constructed immediately after earthquake required some form of timber, mostly Piller (Khaba), Pole (Balo) and other supporting materials. Some temporary shelter used planks (Phalek) as wall materials whereas in most cases Zink sheet (Jasta Pata) were used as roofing materials.

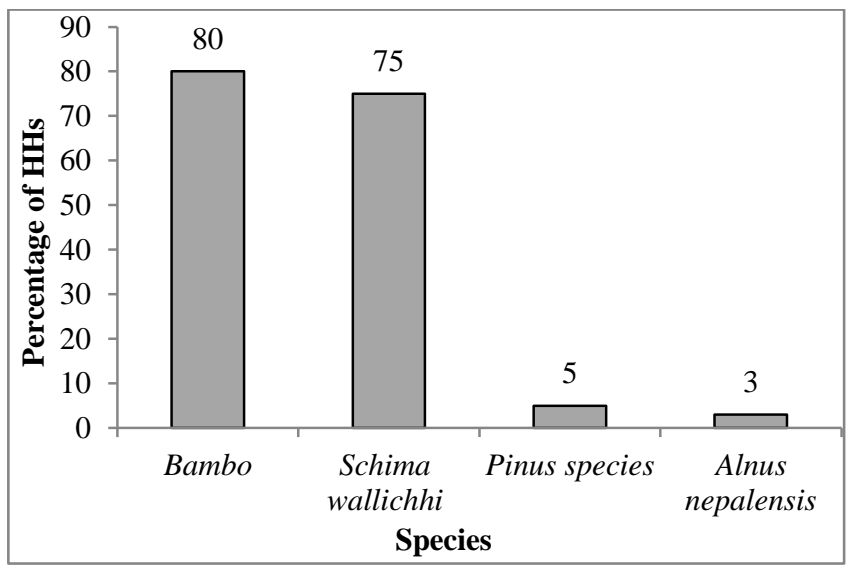

Fig. 3. Major species use for construction of temporary houses.

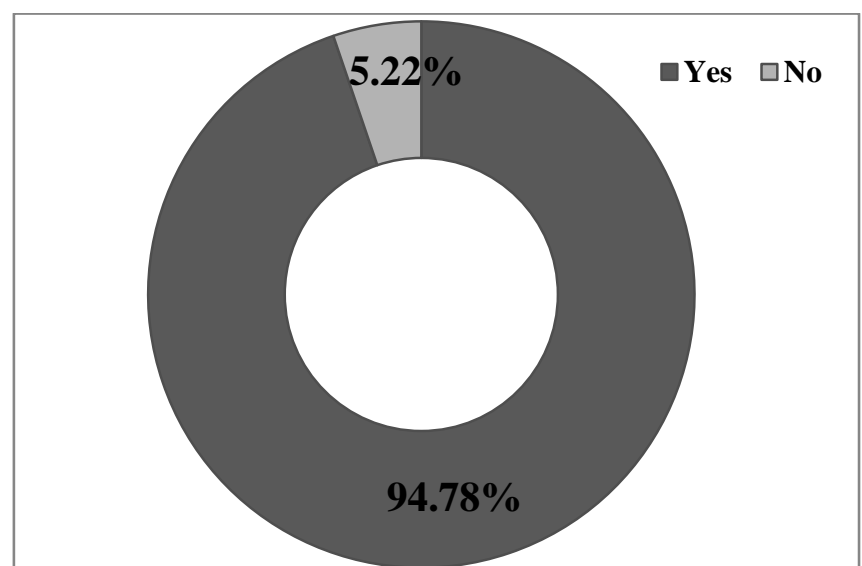

Fig. 4. Peoples 'response on importance of Tree outside forest.

Nearly $80 \%$ of the households used Bamboo for piller pole, supporting materials (dada, choya) to hold and adjust roofing and wall materials. In $75 \%$ of surveyed HHs used Chiluane (Schima wallichii) timber was used for piller and pole (Fig. 3). Very few HHs use of other species like Utis (Alnus nepalensis), Salla (Pinus species) to construct temporary houses (Table 2).

Table 2. Form of construction materials from various species.

\begin{tabular}{lc}
\hline Species & Purposes \\
\hline Bamboo & Balo, Danda, Vata, Choya, Khamba (Piller) \\
\hline Chilaune (Schima wallichii) & Khamba (Pillar), Pole (balo) \\
\hline Khote Salla (Pinus roxburghii) & Balo, Falek (planks) \\
\hline Utis (Alnus nepalensis) & Pillar (Khanba), Balo, Falek \\
\hline
\end{tabular}

Among four commonly used species for construction of temporary houses are Bamboo, Chilaune (Schima wallichii) was mainly extracted from own land or neighbour land. Bamboo was either collected from TOF or burrowed from neighbors land (TOF) but was not extracted from community forestry. Unlike bamboo, extraction of Chilaune (Schima wallichii) from neighbor's land was insignificant (one of the durable timbers of that locality and permanent house construction was in sight). In some cases Chilaune was extracted from community forests (Table 3).

Table 3: Sources of species collected/extracted for construction of temporary houses and percentage from various sources by species.

\begin{tabular}{lcccc}
\hline Sources & \multicolumn{4}{c}{ Extraction percentage (ranges) } \\
\cline { 2 - 5 } & Chilaune & Bamboo & Salla & Utis \\
\hline Own land & $0-100$ & $0-100$ & $0-20$ & $0-5$ \\
Neighbour land & $0-10$ & $0-45$ & $0-5$ & $0-5$ \\
Purchase (neighbour land) & $0-20$ & $0-20$ & $0-30$ & $0-40$ \\
Community Forest & $0-5$ & 0 & $0-100$ & $0-100$ \\
\hline
\end{tabular}




\section{Possible contribution of TOF in permanent house construction}

Even though reconstruction process was just began in study area. Potential contribution of TOF in permanent house building varied with number of trees or species available in their access. Households having sufficient number of trees in farmland point out that TOF will contribute satisfactorily in permanent household constructions (Table 4).

Table 4: Potential contribution of TOF in permanent house construction.

\begin{tabular}{lccc}
\hline $\begin{array}{l}\text { Contribution } \\
\text { percentage }\end{array}$ & $\begin{array}{c}\text { Percentage } \\
\text { of HHs }\end{array}$ & $\begin{array}{c}\text { Average number of } \\
\text { trees in farmland }\end{array}$ & Dominant species in farm land \\
\hline Less than 20 & 10 & less than 100 & Litsea monopetala, Schima wallichii \\
\hline $20-40$ & 40 & 240 & Litsea monopetala, Schima wallichii, Bamboo species \\
\hline $40-60$ & 26 & 500 & $\begin{array}{c}\text { Litsea monopetala, Schima wallichii, Shorea robusta, } \\
\text { Diospyrus kaki, Choerospondias axxillaris }\end{array}$ \\
\hline $60-80$ & 15 & more than 600 & $\begin{array}{c}\text { Litsea monopetala, Schima wallichii, Shorea robusta, } \\
\text { Pinus species, Bamboo species }\end{array}$ \\
\hline More than 80 & 9 & more than 1000 & $\begin{array}{c}\text { Litsea monopetala, Schima wallichii, Shorea robusta, } \\
\text { Pinus species, Bamboo species }\end{array}$ \\
\hline
\end{tabular}

Importance of TOF in disastrous situation

The existence of tree in farmland is a part of traditional as well as contemporary farming systems in rural areas of both developed and developing countries. On one hand, it plays an important role to sustain and restore the physical environment, particularly through enrich soil fertility, reduce erosion, improve air and water quality, enhance biodiversity and sequester carbon. On the other hand, it is a good source of financial support for rural household economy, through food, fuel, fodder, employment and income (Pain-Orcet and Bellefontaine 2004, Garrity et al. 2006). Out of 134 households surveyed, 94.78\% (127 HHs) respondents reported that there is great important of farm trees in disastrous situations (Fig. 4). However, 5.22\% respondents have no response to the situation. People believe that presence of tress in farmland was easily accessible and were extracted as per need. Hence, the importance of tree outside forest for immediate requirement cannot be neglected.

Trees outside forest (TOF) comprises of trees that are not included in definition of forest and may be a tree formation ranging from a tree standing alone discretely to those that have been systematically arranged in an agroforestry system (Kleinn 2000). They may also include trees scattered in agriculture land, including pastures, and meadows, barren land and built on land with infrastructures. These trees outside forests implicitly offer wide range of ecological, economic, social and religious functions (Idol et al. 2011). In Thulosirubari village trees are either protected or preserved in terrace raiser, fallow land or boarder land. Farmers of hilly reason grow trees in rainfed terraces or on degraded land where species like Alnus nepalensis, Litsea monopetala, Schima wallichii etc. are dominant one (Amatya 2018). Species like Chilaune, Kutmiro, bamboo, pine etc. are dominant species in TOF in the study location. These species are mainly preserving or conserving for fodder, timber, fuel wood, however supporting role played by trees to improve soil quality, reduce soil erosion, stabilize slope. In the countries like Nepal, people are growing trees in private land to fulfill their basic needs of forest product as well as to generate alternative sources of income. TOF have been associated with livelihood of rural people especially in mid-hills of Nepal where contribution of TOF in fuel wood, timber, fodder cannot be underestimated (Oli 2002). Amatya (2018) highlighted that trees in farmland are mainly multipurpose and choices are governed by primary household needs.

There were only few HHs, who does not have trees on their farmland. Number and species available are highly influenced by amount of land hold by farmers. In an average there were 50 trees per household in the study sites. Previous studies found that the number of trees per farm varies with an 
average of 15 in the Koshi hills (Virgo and Subba 1994) to 53 in western Nepal (Fonzen and Oberholzer 1984). Even though this study does not consider about biomass available in TOF but this is one of the important sources of woody biomass and hold substantial part of national woody biomass (Schnell et al. 2015).

Species like Bamboo, Schima wallichii, Pinus species were collected from own land (TOF) and neighbor land, but Uttis was collected from community forests. It shows that easily available and cheap timber were collected for construction of temporary house, it is mainly due to availability of timbers from old damaged house. Bamboo and Chilaune were major source of timber for construction of temporary houses where Chilaune species were the major tree species on own land. Bamboo was extracted or collected from neighbor land as supporting materials for construction of temporary house. From the study it was seen that total contribution of TOFs for timber required for reconstruction after Earthquake, 2015 was determined by three factors; number of trees present, types of tree present and the proximity to forest. Those HHs with sufficient trees in their backyard but living near to the forests choose to use more durable species form the Community forests. The most preferred species for the construction of permanent houses were Schima and Pinus, as they were easily available in the study area and were less expensive than more durable species from community forest. Bamboos were also among the preferred species mostly used as supporting material to support mud in between stories. Hence, TOF can produce wide range of products and services (Kang and Akinnifesi 2000, Idol et al. 2011) like timber, fire wood, fruits, fodder, medicines etc. (Amatya 2018) which can directly be traded. These trees that are present outside of the general extent of forest and prevalent in farm land, mostly those planted in terrace help in stabilizing slopes and minimizing risk of hazards (FAO 2011).

The study shows that TOF have visible and significant importance on immediate recovery from earthquake and other disastrous damages. Schima wallichii, Litsea monopetala, Bamboo, Pinus species, and other fruit trees like Choerospondias axillaris, Diospyrus kaki were common species in TOF. A wide variety of tree species recorded in farm land shows that TOF are repository of high plant diversity as farm trees particularly in home gardens, terrace raising, fallow land, border land, mainly preserve/planted for fodder, fuel wood, timber etc. TOF were prime source of timber for construction of temporary household followed by TOF from neighbour (Mainly Bamboo, 80\%) and Schima wallichii (75\%). For construction of Temporary houses very little amount of timber was extracted from government forests or community forests. Most of the people believed that these trees are ecologically and economically important thus signifying their huge importance during the time of disasters like earthquake.

\section{ACKNOWLEDGEMENTS}

This study was funded by the Directorate of Research and Extension (DoRE), Agriculture and Forestry University, Nepal. The authors express sincere gratitude to the local people of Thulosirubari village for providing information during questionnaire survey.

\section{REFERENCES}

Amatya, S. M., E. Cedamon and I. Nuberg. 2018. Agroforestry systems and practices in Nepal. Revised ed. Agriculture and Forestry University, Rampur, Nepal. 108 pp.

Benfield, A. 2015. 2015 Nepal Earthquake Event Recap Report, (September, 2015). http://wiki.openstreetmap.org/wiki/2015_Nepal_earthquake

CBS. 2012. National Population and Housing Census 2011(National Report). National Planning Commission Secretariat, Central Bureau of Statistics, Government of Nepal. 1: 1-278. 
DDC. 2016. Sindhupalchok District Profile, 2016. Sindhupalchok disttrict, Bagmati Zone, Nepal.

FAO. 2003. Trees outside forests, a key factor in integrated urban and rural management - Food for thought. First Part. Food and Agriculture Organization of the United Nations, Rome, Italy. 58 pp.

FAO. 2004. National Forest Inventory - Field Manual Template. Forest Resources Assessment Programme No. 94/E. Food and Agriculture Organization (FAO) of the United Nations, Rome, Italy. $86 \mathrm{pp}$.

FAO. 2011. Forests and Landslides - The role of trees and forests in the prevention of landslides and rehabilitation of landslide-affected areas in Asia. Food and Agriculture Organization (FAO) of the United Nations Regional Office for Asia and the Pacific, Bangkok, Thailand. 70 pp.

Fonzen, P. F. and E. Oberholzer. 1984. Use of multipurpose trees in hill farming systems in Western Nepal. Agroforestry Syst. 2: 187-197.

Garrity, D., A. Okono, M. Grayson, and S. Parrott. 2006. World Agroforestry into the Future. World Agroforestry Centre, Nairobi, Kenya. 212 pp.

Idol, T., J. Hagger and L. Cox. 2011. Ecosystem services from smallholder forestry and agroforestry in the tropics. In: W. B. Campbell and S. L. Oritz (eds.). Integrating agriculture, conservation and ecotourism: example from the field. Springer, Dordrecht, Germany., pp. 209-270.

Kang, B. T. and F. K. Akinnifesi. 2000. Agroforestry as Alternative Land-Use Production System for the Tropics. Natural Resources Forum. 24(2): 137-151.

Giri, N. 2004. Assessment of tree resources outside forests: a lesson from Tanzania. Banko Janakari. 14(2): 46-52.

Gnyawali, K. R., S. Maka, B. R. Adhikari and D. Chamlagain. 2016. Spatial implications of earthquake induced landslides triggered by the April 25 Gorkha earthquake Mw 7.8 : preliminary analysis and findings. International Conference on Earthquake Engineering and Post Disastor Reconstruction Planning, 24-26 April, 2016. Bhaktapur, Nepal., pp. 1-10.

Kleinn, C. 2000. On large-area inventory and assessment of trees outside forests. Unasylva 200. 51: 1-10.

MoHA. 2015. Nepal Earthquake 2072: Situation Update as of $11^{\text {th }}$ May 2015. Ministry of Home Affairs, Nepal. 4 pp.

MoSTE. 2015. Nepal Earhquake 2015: Rapid Environmental Assessment. Ministry of Science Technology and Environment, Kathmandu, Nepal. 102 pp.

Nepal, S. M. 2015. Impact of Earthquake on Ecosystem and Biodiversity. WWF Reporting. 26 pp.

NPC. 2015. Nepal Earthquakes 2015: Post Disaster Needs Assessment Vol. B: Sector Reports. National Planning Commission (NPC), Goverment of Nepal, Singhadabar, Kathmandu, Nepal. 312 pp.

Oli, B. N. 2002. Trees outside forests: an ignored dimension of forest resource assessment. Banko Janakari. 12(1): 79-81.

Pain-Orcet, M. and R. Bellefontaine. 2004. Trees outside the forest: A new perspective on the management of forest resources in the tropics. In: D. Babin (ed.). Beyond Tropical Deforestation. UNESCO/CIRAD, Paris, France., pp. 423-430. 
Schnell, S. 2015. Integrating trees outside forests into national forest inventories. Doctoral Thesis. Faculty of Forest Sciences. Department of Forest Resource Management, Swedish University of Agricultural Sciences, Umea, Sweden. 74 pp.

Schnell, S., D. Altrell, G. Stahl and C. Kleinn. 2015. The contribution of trees outside forests to national tree biomass and carbon stocks - a comparative study across three continents. Environ. Monit. Assess. 187(1): 1-18.

Shrestha, H. L., N. Chapagain, K. R. Dhital and S. Adhikari. 2016. Geospatial analysis of forest resources availability for the reconstruction after Earthquake 2015. International Federation of Surveyors. 2016: 1-16.

Virgo, K. J. and K. J. Subba. 1994. Land-Use Change between 1978 and 1990 in Dhankuta District, Koshi Hills, Eastern Nepal. Mountain Res. Develop. 14(2): 159-170.

West, P. W. 2009. Tree and Forest Measurement. 2nd ed. Springer-Verlag Berlin Heidelberg, Germany. $192 \mathrm{pp}$. 